\title{
A STUDY OF THE ULTRASTRUCTURE OF THE UTEROVAGINAL SPERM-STORAGE GLANDS OF THE HEN, GALLUS DOMESTICUS, IN RELATION TO A MECHANISM FOR THE RELEASE OF SPERMATOZOA
}

\author{
W. H. BURKE,* F. X. OGASAWARA AND C. L. FUQUA \\ University of California, Davis, California 95616, U.S.A.
}

(Received 17th March 1971, accepted 30th Fune 1971)

\begin{abstract}
Summary. The general ultrastructure of the storage tubules for spermatozoa at the junction of the uterus with the vagina in the domestic fowl at various stages in the egg-laying cycle has been examined. Secretions were produced by tubule cells but no evidence was observed of a cyclic secretion of material into the lumen of tubules corresponding with the movement of ova in the oviduct and with the time of oviposition. Thus, a mechanism for the periodic flushing of spermatozoa from the tubules before the fertilization of ova in the upper region of the oviduct was considered unlikely to occur.
\end{abstract}

\section{INTRODUGTION}

Production of fertile eggs by hens for an extended period of time after a single insemination or mating has been recognized for many years. The sites in which spermatozoa are stored in the hen's oviduct, allowing a prolonged production of fertile eggs, has been the subject of a number of recent studies. Van Drimmelen (1946) described 'sperm nests' in the infundibular region of the oviduct, which contained spermatozoa after natural mating or intraperitoneal artificial insemination. Bobr (1962) and Bobr, Lorenz \& Ogasawara (1964) confirmed this observation, but found many more spermatozoa stored in tubular glands in the region of the uterovaginal (UV) junction. They suggested that the UV glands are the normal sites of residence for spermatozoa in the oviduct of the hen. This suggestion has been supported by Van Krey (1964), Schindler, Ben-David, Hurwitz \& Kempenich (1967) and Takeda (1967), and by unpublished observations in this laboratory. Fujii \& Tamura (1963), however, found substantial numbers of spermatozoa in both the UV and infundibular storage sites after natural matings.

The microscopic structure of the UV sperm-storage glands has been described by Bobr (1962), Fujii \& Tamura (1963), and Bobr, Lorenz \& Ogasawara (1964). Essentially, these structures are tubular glands, mostly unbranched with an outside diameter of approximately $70 \mu \mathrm{m}$ (Fujii \& Tamura, 1963). The

* Present address: Department of Animal Science, University of Minnesota, St Paul, Minnesota 55101, U.S.A. 
length of the glands has not been precisely established but a value of 200 to 300 $\mu \mathrm{m}$ is probably in the correct range (unpublished observations). The value of $1 \mathrm{~cm}$ given by Fujii \& Tamura (1963) is undoubtedly high. The glands arise as invaginations of the UV mucosa, often from the base of mucosal crypts. While the mucosa and the crypts have pseudostratified, ciliated columnar epithelia, the tubular glands are composed of a single layer of columnar cells with a mean height of about $16 \mu \mathrm{m}$ (unpublished observations).

The ultrastructure of the UV sperm-storage sites was investigated by Van Krey (1964) and Van Krey, Ogasawara \& Pangborn (1967) to determine if contractile elements were associated with the glands which might serve in the release of spermatozoa from the storage sites. No evidence of such elements was found, but these investigators noted an accumulation of dense secretory granules in the apices of the cells lining the glands. Schindler et al. (1967) examined the sperm-storage tubules with the electron microscope to determine the relationship of spermatozoa to the tubule cells. They were unable to confirm the observations of Fujii \& Tamura (1963) that spermatozoa penetrated the intercellular spaces of the tubules.

The mechanism by which spermatozoa are released from the UV spermstorage tubules has been studied for several years in this laboratory. The work of Bobr (1962), Bobr, Ogasawara \& Lorenz (1964) and Van Krey (1964) indicated that the release of spermatozoa from the tubules was restricted to the time of oviposition, or ovulation or both.

The apical accumulations of secretory granules in cells of the sperm storage sites, as shown in electron micrographs (Van Krey, 1964), indicate a possible mechanism by which spermatozoa could be released periodically from the storage tubules. If there was cyclical production of secretory material from the tubule cells, a hypothetical mechanism could be envisaged by which spermatozoa would be flushed from the storage tubules by this material. An experiment was designed to examine such a mechanism. The general ultrastructure of the UV sperm storage tubules was studied in hens around the time of oviposition and aspects of the ultrastructure were critically examined for indications of the possible mechanism by which spermatozoa might be released cyclically from the storage tubules.

\section{MATERIALS AND METHODS}

White Leghorn hens in the first year of egg production were killed around the time of oviposition (from about $2 \mathrm{hr}$ before to $2 \mathrm{hr}$ after) which on the basis of the work of Bobr (1962), Bobr, Ogasawara \& Lorenz (1964) and Van Krey (1964), was the assumed time of release of spermatozoa from the UV glands. Records of oviposition time were obtained for several weeks before each hen was used (Mather, Wilson \& Woodard, 1965).

Hens were killed by cervical dislocation. The oviduct was removed and the UV region was separated from the rest of the oviduct. A longitudinal cut was made in the region and a section was placed in a Petri dish containing $1 \%$ saline. Small pieces of tissue containing sperm storage tubules were removed using iridectomy scissors and watchmaker's forceps, placed in a second Petri dish 
containing saline and then examined using a dissecting microscope at $\times 30$ magnification. With transmitted light, it was possible to determine the presence of sperm-storage tubules in these samples. Pieces of tissue containing sperm storage tubules were cut into approximately $2 \mathrm{~mm} \times 5 \mathrm{~mm}$ sections and placed in cacodylate-buffered $5 \%$ gluteraldehyde at $\mathrm{pH} 7 \cdot 3$ to $7 \cdot 4$.

After fixation for at least $2 \mathrm{hr}$, the tissue was transferred to buffer solution until further processing. After rinsing in three changes of cacodylate buffer overnight, the tissue was placed in $1 \%$ osmium tetroxide solution for $2 \mathrm{hr}$, dehydrated in graded ethyl alcohol solutions, treated with graded propylene oxide solutions and embedded in a mixture of Epon and Araldite. The blocks were hardened in an oven at approximately $60^{\circ} \mathrm{C}$ for 12 to $24 \mathrm{hr}$.

The blocks containing embedded tissue were trimmed with a razor blade in a holder especially adapted for the base of a dissecting microscope. The holder allowed the transmission of light through the blocks from below. By examining the blocks, using $\times 30$ magnification, the individual sperm storage tubules could be identified. The blocks were then trimmed towards individual tubules to avoid sectioning the tissue not containing storage tubules. The blocks were trimmed into a truncated, pyramidal shape, with the large side of the block measuring about $0.5 \mathrm{~mm}$.

Blocks were sectioned on either a Porter-Blum MT1 or MT2 ultramicrotome, with either glass or diamond knives. Sections ranging from silver to grey were spread with xylene vapours and picked up on uncoated copper grids of 200 or 300 mesh. Sections were stained with saturated aqueous uranyl acetate for 30 min, followed by staining for $2 \mathrm{~min}$ with lead citrate stain (Reynolds, 1963). Between the two stains, and after the final stain, the sections were washed in distilled water. All staining and washing was done on a porcelain spot plate.

Grids were examined using an RGA EMU 3E or 3G electron microscope.

\section{RESULTS}

The abundance of electron-dense secretory granules in the apices of cells at the orifice of UV glands (Van Krey, 1964) was confirmed (Pl. 1, Fig. 1); cells with such granules were rarely found deeper in the gland. The granular cells were similar to the apical cells of the uterine epithelium (Johnston, Aitken \& Wyburn, 1963) and were restricted to the invagination of the UV epithelium which gives rise to the sperm storage tubules (see Pl. 1, Fig. 2). These cells were usually ciliated and often have long microvilli interspersed among the cilia (Pl. 1, Fig. 1).

One of the more characteristic features of cells in the distal region of the storage tubule was an accumulation of vesicles in the perinuclear region. These vesicles range up to $1.5 \mu \mathrm{m}$ in diameter. In some cells, the vesicles were not apparent; in others, material similar to the vesicles were not apparent; in others, material similar to the vesicular material was present, but not arranged in vesicular form (Pl. 1, Figs. 3 and 4). The vesicles are generally electron-lucent, but sometimes a moderate amount of denser material is present in the periphery or in the centre (Pl. 1, Fig. 4). Often many vesicles are present in the infranuclear region of the cells and, in certain instances, fusion of several round vesicles 
is evident. Areas of electron lucency which are not arranged into round vesicles are sometimes seen with which free ribosomes are often associated (Pl. 1, Figs. 3 and 4).

Modifications of the plasma membranes in tubule cells include abundant microvilli (Pl. 2, Fig. 5) and extreme examples of lateral wall interdigitations in the basal regions of some cells (Pl. 2, Fig. 7); however, the basal membrane itself is relatively free of interdigitations. Cilia are conspicuously absent from the luminal surface of true tubule cells (Pl. 1, Fig. 4 and Pl. 2, Fig. 5).

Basal nuclei are generally round in outline and free from indentation in tubule cells (Pl. 1, Figs. 3 and 4) although occasionally the nuclei have a more distorted circular form. The cross-sectional diameters of the nuclei are about 4 to $8 \mu \mathrm{m}$.

\section{EXPLANATION OF PLATES}

\section{PLATE 1}

FIG. 1. Electron micrograph of the orifice region of a uterovaginal (UV) sperm storage tubule. The presence of cilia (C) and electron-dense secretory granules (SG) are indicative of this region of a UV sperm-storage tubule. $\times 6400$.

FIG. 2. Light micrograph of a branched UV sperm storage tubule. A pseudostratified, ciliated invagination of the vaginal epithelium can be seen giving rise to two UV sperm storage tubules $(\mathrm{ST})$ composed of a single layer of a columnar cells with basal nuclei. Spermatozoa $(\mathrm{Sp})$ are seen within the lumen of the tubule. $\times 175$.

FIG. 3. Electron micrograph of the adjacent region of the UV sperm storage tubule shown in Fig. 4. Fringes of electron-dense material can be seen around the electron-lucent vacuoles (V). Areas of electron lucency are evident which are not arranged in vacuolar form and an abundance of ribosomes can be seen in these regions. $\times 4060$.

FIG. 4. Electron micrograph of UV sperm storage tubule. Note the basal location of the nuclei $(\mathrm{N})$, the columnar nature of the cells, the distribution of the mitochondria $(M)$, the variable distribution of the electron-lucent material and associated ribosomes and compare it with the same material in Fig. 3 which is an adjacent region of the same tubule. Lysosomes (L) can be seen in the apical region of some of the cells. Accumulations of fibrils (F1) are apparent in the nuclear region of the cells, oriented in the long axis of the cells. $\times 4060$.

\section{PLATE 2}

Fig. 5. Electron micrograph of the apical region of cells of a UV sperm storage tubule and the lumen of the tubule. Abundant microvilli (MV) are apparent, some of which are enlarged into secretory blebs (B). Cross-sections of spermatozoa through the heads (SH), the midpieces $(\mathrm{SMp})$ and the tails $(\mathrm{ST})$ are seen. $\times 6090$.

FIG. 6. Electron micrograph of a UV sperm storage tubule. This oblique section demonstrates the lateral wall interdigitations of the plasma membrane (PM). Collagen fibres (CF) can be seen outside of the tubule. A distinct cell type, tentatively identified as a lymphocyte $(\mathrm{Lym})$, is seen between true tubule cells. $\times 3400$.

FIG. 7. Electron micrograph of the basal regions of a UV sperm storage tubule. The extreme interdigitations of the lateral plasma membrane (PM) can be seen in this micrograph. Rough endoplastic reticulum ( $\mathrm{Re})$ is not abundant in region of nucleus. A capillary (not shown) was located within $1 \mu \mathrm{m}$ of the base of these cells, directly adjacent to the junction of the cells. $\times 12,600$.

\section{PLATE 3}

FIG. 8. Electron micrograph of the basal region of a UV sperm storage tubule showing filamentous bundles $(\mathrm{F} 1) . \times 6300$.

Fig. 9. Electron micrograph of a UV sperm storage tubule. The lumen of the tubule is nearly filled with macroapocrine secretory droplets (SD). A spermatozoon $(\mathrm{Sp})$ is seen in the tubule lumen. $\times 4480$.

Fig. 10. Electron micrograph of the lumen region of a UV sperm storage tubule showing the peripheral localization of sperm heads (SH). Spermatozoa are seen in planes ranging from true cross-sections to nearly longitudinal section. $\times 4750$. 


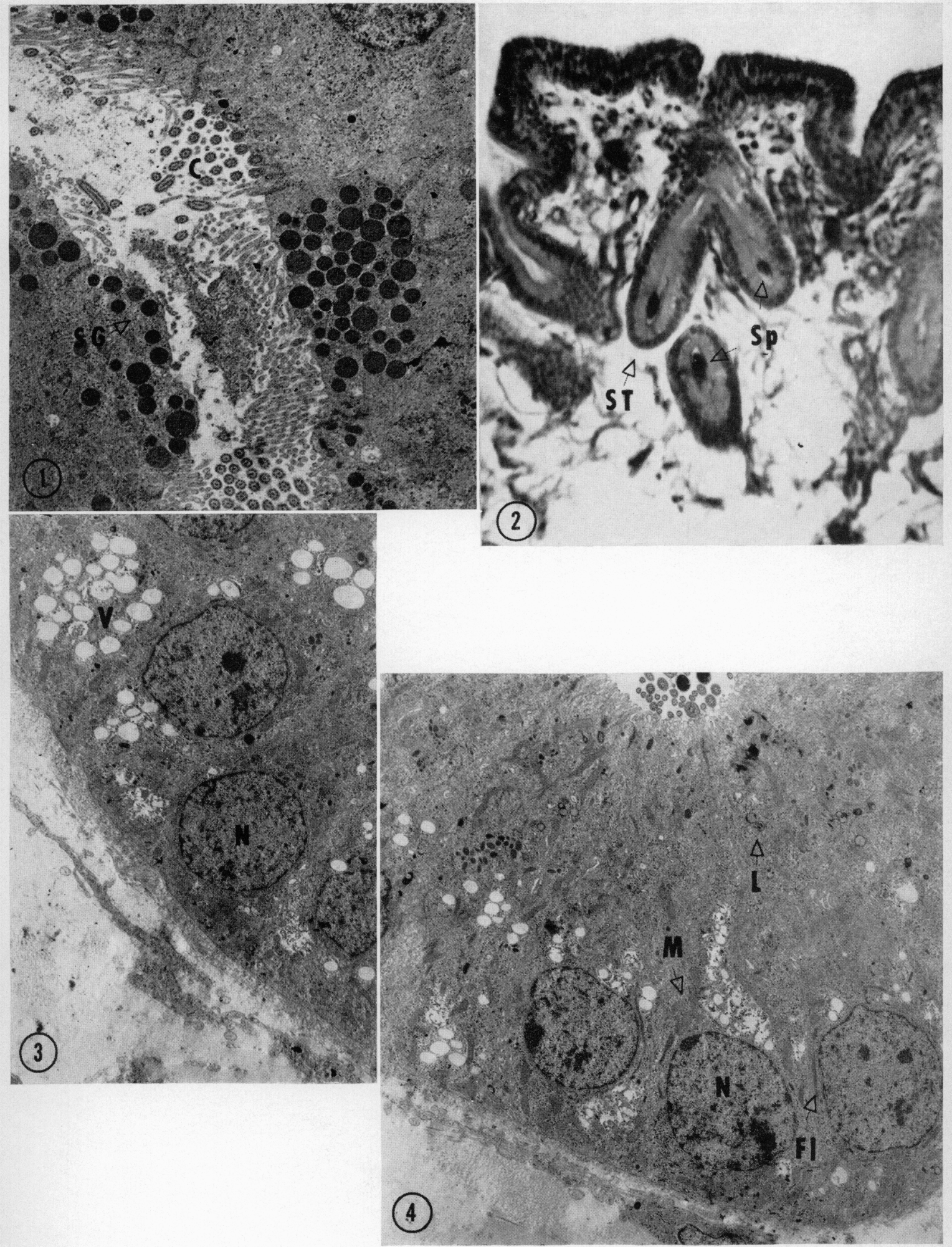




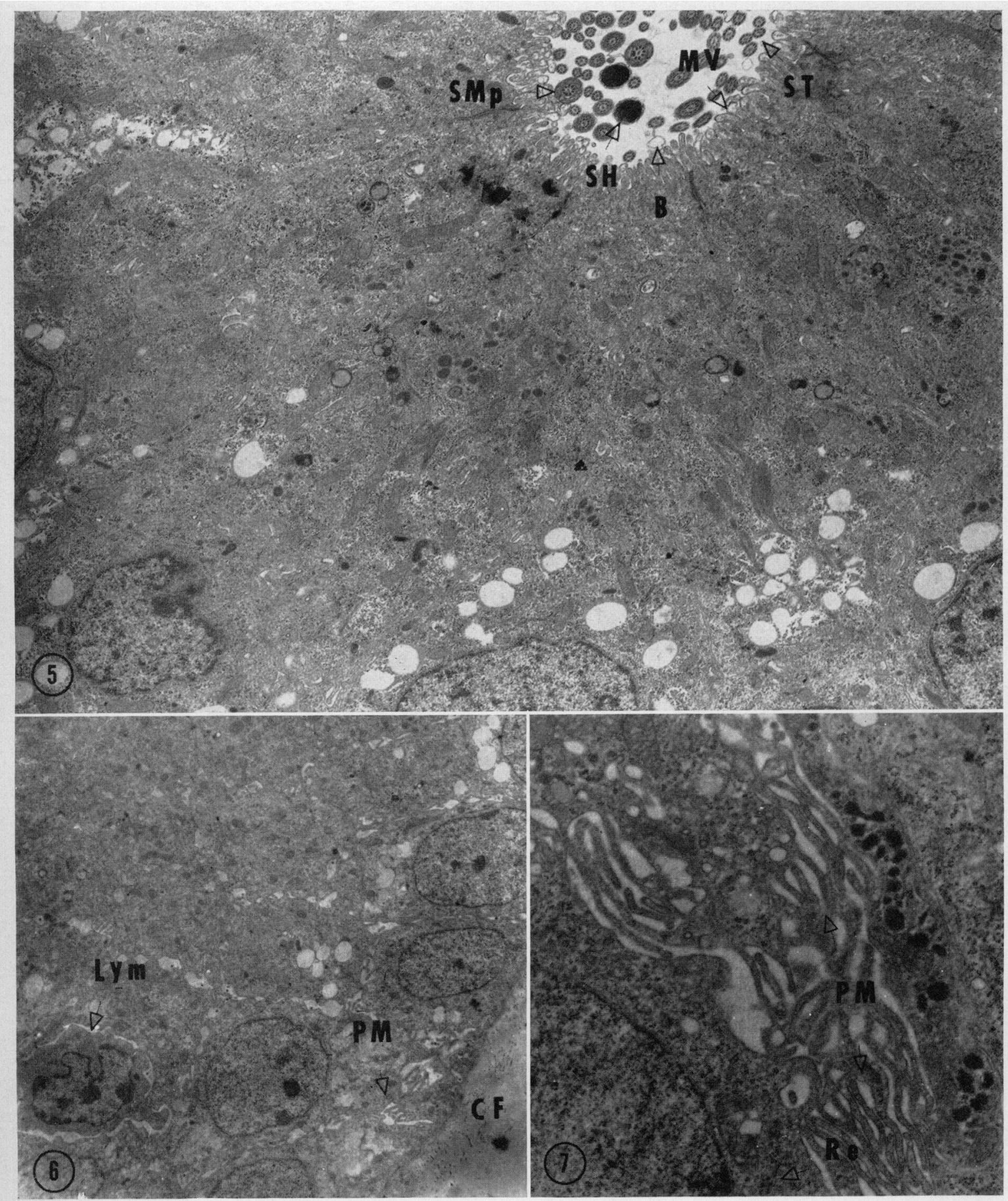



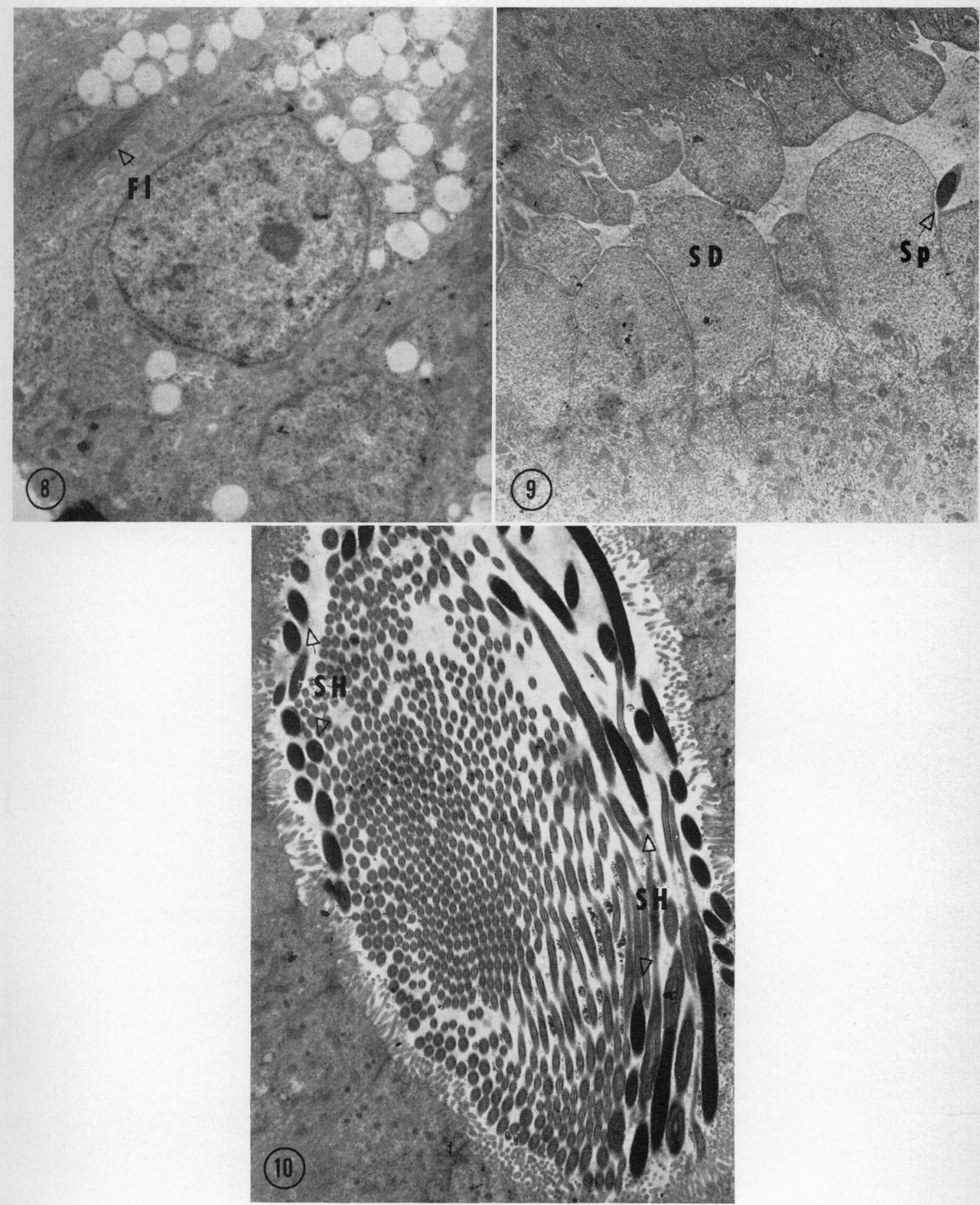
Mitochondria, rod-shaped and sometimes branched, are distributed throughout the cytoplasm of tubule cells. In the infranuclear region, the mitochondria tend to be orientated parallel to the long axis of the cells, while the supranuclear mitochondria appear more randomly orientated. The mitochondria are approximately 0.1 to $0.4 \mu \mathrm{m}$ in width and up to $2.0 \mu \mathrm{m}$ in length.

Very little rough endoplasmic reticulum is seen in the tubule cells; but, when present, it tends to be located in the perinuclear region (Pl. 2, Fig. 7). Filamentous inclusions, clustered into bundles as large as $0.1 \times 3.0 \mu \mathrm{m}$ and oriented parallel to the long axis of the cells, are frequently observed in tubule cells (Pl. 3, Fig. 8).

A classical Golgi apparatus, with its lamellar arrangement of membranes and associated vesicles, was not seen in the cells of sperm storage tubules.

Although the distal cells in the sperm storage tubules do not have the dense secretory granules, they are true secretory cells. The mode of secretion is apocrine and both the Type II and Type III secretions of Kurosumi (1961) are seen (Pl. 2, Fig. 5 and Pl. 3, Fig. 9). Type III secretion was the most common in this study, and examples of it were seen in nearly every cross-section of the sperm storage tubules. Only one example of the Type II, i.e. macroapocrine secretion, was noted (Pl. 3, Fig. 9). This was in a hen killed $156 \mathrm{~min}$ after oviposition, with an ovum in the magnum. In this hen, blebs of secretory material up to approximately $8 \mu \mathrm{m}$ in height and 5 to $6 \mu \mathrm{m}$ in width were present. Only one tubule was seen with this degree of secretory activity. Extensive search of other tissue from the same hen failed to reveal other tubules in the same state.

Examination of tissue from twenty-two hens killed at various times up to about $2 \mathrm{hr}$ before and after oviposition disclosed no differences which could be related to the ovulatory cycle. For instance, there appeared to be as great a variation in the secretory activity of different cells in the same tubule as there was between cells in tubules taken from different hens, examined throughout the experimental period. The condition of the perinuclear vacuoles, the presence of secretory blebs on microvilli and the con tion of the mitochondria were noted as indices of secretory activity.

The relationship of the spermatozoa to the storage tubules was of interest in trying to understand the release mechanism. Van Krey (1964) suggested that the heads of spermatozoa become embedded in the microvilli of the tubule cells, while Fujii \& Tamura (1963) stated that the spermatozoa actually enter the intercellular spaces of the tubules. Neither of these two conditions was found in the present study. In densely populated tubules, some spermatozoa were seen touching the tips of the microvilli but never embedded in them. Cross-sections of some tubules revealed spermatozoa cut at different levels; in the same micrographs, cross-sections through sperm heads, through mid-pieces and through tails were evident (Pl. 1, Fig. 4, Pl. 2, Fig. 5 and Pl. 3, Fig. 10). There appeared to be a tendency for sperm heads to localize peripherally, and tails centrally, in tubule lumina (Pl. 3, Fig. 10) when both heads and tails were seen at the same level of sectioning.

No morphological differences were noted between spermatozoa in the storage tubules and those free in the testes as described by Nagano (1962).

During the course of these studies, a type of cell was seen interspersed between 
true tubule cells which differed from them morphologically. It was roughly round in outline, but had many irregular projections from its outer plasma membrane. The cell was approximately 6 to $7 \mu \mathrm{m}$ in diameter and consisted of a large nucleus surrounded by a border of cytoplasm (Pl. 2, Fig. 6). Nuclear chromatin material, often irregular in outline and indented, was accumulated into large clumps on the periphery and in the centre of the nucleus. Little cytoplasmic detail was evident at the magnification at which these cells were observed. The cells were observed at all levels between tubule cells, from the basal region to near the apical region; some were very close to the junctional complex. However, none were observed in tubule lumina. On the basis of cell size, nuclear characteristics, amount of cytoplasm and location in the tissue, we suggest that these cells are lymphocytes. This conclusion is further supported by the work of Ackerman (1962) and Maxwell \& Trejo (1970).

\section{DISCUSSION}

Examination of the ultrastructure of storage tubule cells in the UV tissue of hens killed at one of several times before or after oviposition revealed no evidence of cyclic secretory activity. The tissue, however, is secretory, as evidenced by the extrusion of material into tubule lumina (Pl. 2, Fig. 5, Pl. 3, Figs. 9 and 10).

The chemical nature of the secretory products of the cells could not be determined from morphological studies alone but some analogies can be drawn between the ultrastructure of the tissue studied and the ultrastructure of cells highly specialized for the secretion of known products.

An extensively developed, rough endoplasmic reticulum appears to be ubiquitous among cells that are actively secreting protein (Haguenau, 1958; Kurosumi, 1961; Junqueira, 1965). Most, but not all, cells which produce and extrude protein do so in the form of secretory granules; and a well developed Golgi apparatus is seen in these cell types (Pollister \& Pollister, 1957; Porter, 1961; Jamieson \& Palade, 1967). F wever, in certain albumin-secreting cells in the hen's oviduct, the possible involvement of the Golgi apparatus in the secretory process appears less clear (Hendler, Dalton \& Glenner, 1957). The sparsity of rough endoplasmic reticulum and the lack of an identifiable Golgi apparatus seem to preclude a protein-secreting rôle for sperm storage cells. The absence of an abundant protein-secreting apparatus is in agreement with the histochemical findings of Gilbert, Reynolds \& Lorenz (1968).

Extensive development of smooth endoplasmic reticulum has been associated with steroid secretion in the testes. Another characteristic of steroid-producing cells is the tubular nature of the mitochondrial cristae (Kurosumi, 1961). Absence of these two features in the sperm storage tubule cells might indicate an absence of this particular group of compounds as secretory products.

Glycogen secretion has been related to highly developed, smooth endoplasmic reticulum in the liver (Porter, 1961). The absence of such a reticulum in the sperm-storage tubule cells may indicate that the storage of glycogen is not a primary function of these cells. However, Gilbert et al. (1968) identified glycogen histochemically in the cells of the storage tubules and in a tubule lumen of one hen killed shortly after oviposition. 
Histochemical studies of the sperm storage tubules clearly indicate the presence of lipid in the perinuclear region of the cells (Fujii, 1963; Gilbert et al., 1968), but these authors disagree as to the nature of the lipid. Fujii considers the material to be cholestrin esters, and has demonstrated the presence of such esters in the tubule lumina of one hen. Gilbert et al. (1968) feel that the lipid in the infranuclear region is an acidic phospholipid and that the lipid in the supranuclear region is predominantly non-phospholipid. The latter authors were unable to confirm Fujii's finding of lipid in the tubule lumina at the time of oviposition. It seems likely that the perinuclear accumulations of lipid in the two histochemical studies quoted have their counterpart in the electron micrographs in the present study. A characteristic feature of the perinuclear region of the cells in the electron micrographs is the presence of large electron-lucent vacuoles. On a topographical basis alone, it is reasonable to consider that these vacuoles are similar to the organelles stained by the lipid stains in the histochemical studies. In many of the electron micrographs, it appears that a major portion of the vacuolar contents has been removed, leaving empty or nearly empty spaces.

High levels of acid phosphatase were found in the apical region of the storage tubule cells by Gilbert et al. (1968). This enzyme is often associated with lysosomes, but only a few were seen in electron micrographs (Pl. 1, Fig. 4).

It has been suggested by Bobr, Ogasawara \& Lorenz (1964) that numbers of spermatozoa leave the storage tubules in response to unknown stimuli related to ovulation or oviposition. Van Krey (1964) demonstrated that humoral stimuli were not likely to be involved. The present study on ultrastructure has shown that cells of the tubules produce secretions, but no direct evidence of a cyclic production of secretion which could lead periodically to a flushing of spermatozoa in relation to ovulation was observed. Thus, the precise mechanism by which spermatozoa are released from the storage tubules in the UV region of the hen's oviduct for the fertilization of successive ova laid daily remains unknown.

\section{ACKNOWLEDGMENTS}

This investigation was supported in part by a Public Health Service Predoctoral Fellowship Award (1-F1-Gm-ee, 718-01) from the Institute of General Medical Sciences, and in part by the HS 1 A Program, School of Medicine, Univ. Calif., Davis, P.R. 06138.

\section{REFERENCES}

Ackerman, G. A. (1962) Electron microscopy of the Bursa of Fabricius of the embryonic chick with particular reference to the lymphoepithelial nodules. F. Cell Biol. 13, 127.

BOBR, L. W. (1962) Oviducal distribution of spermatozoa and fertility of the domestic fowl. Ph.D. thesis, University of California.

Bobr, L. W., LoRenz F. W. \& Ogasawara, F. X. (1964) Distribution of spermatozoa in the oviduct and fertility in domestic birds. I. Residence sites of spermatozoa in fowl oviducts $\mathcal{F}$. Reprod. Fert. $8,39$.

Bobr, L. W., Ogasawara F. X. \& Lorenz, F. W. (1964) Distribution of spermatozoa in the oviduct and fertility in domestic birds. II. Transport of spermatozoa in the fowl oviduct. F. Reprod. Fert. 8,49 . 
FujII, S., (1963) Histological and histochemical studies on the oviduct of the domestic fowl with special reference to the region of uterovaginal juncture. Archvm histol. jap. 23, 447.

FujII, S. \& TAMURA, T. (1963) Location of sperms in the oviduct of the domestic fowl with special reference to storage of sperms in the vaginal gland. F. Fac. Fish. Anim. Husb. Hiroshima Univ. 5, 145.

Gilbert, A. B., Reynolds, M. E. \& Lorenz, F. W. (1968) Distribution of spermatozoa in the oviduct and fertility in domestic birds. V. Histochemistry of the uterovaginal sperm-host glands of the domestic hen. 7. Reprod. Fert. 16, 433.

Haguenau, F. (1958) The ergastoplasm: its history, ultrastructure and biochemistry. Int. Rev. Cytol. 7, 425.

Hendler, R. W., Dalton, A.J. \& Glenner, G. G. (1957) A cytological study of the albumin-secreting cells of the hen oviduct. 7. biophys. biochem. Cytol. 3, 325.

Jamieson, J. D. \& Palade, G. E. (1967) Intercellular transport of secretory proteins in the pancreatic exocrine cell. I. Role of the peripheral elements of the Golgi complex. 7. Cell Biol. 34, 577.

Johnston, H. S., Artken, R. N. C. \& Wyburn, G. M. (1963) The fine structure of the uterus of the domestic fowl. 7. Anat. 97, 333.

Jungueira, L. C. U. (1965) Aspects of the biology of the animal cell secretion. In: Sekretion und Exkretion, Proc. 2, wissenschaftliche Konferenz der Gesellschaft Deutscher Naturforscher und Arzte Schloss Reinhardsbrunn bei Friedrichroda 1964.

Kurosumi, K. (1961) Electron microscopic analysis of the secretion mechanism. Int. Rev. Cytol. 11, 1.

Mather, F. B., Wilson, W. O. \& Woodard, A. E. (1965) Systems for recording time of oviposition in chicken, turkey and quail. Poult. Sci. 44, 1100.

Maxwell, M. H. \& TREJo, F. (1970) The utrastructure of white blood cells and thrombocytes of the domestic fowl. Br. vet. $\mathcal{F}$. 126, 583.

Nagano, T. (1962) Observations on the fine structure of the developing spermatid in the domestic chicken. F. Cell Biol. 14, 193.

Pollister, A. W. \& Pollister, P. F. (1957) The structure of the Golgi apparatus. Int. Rev. Cytol. 6, 85.

PoRTER, K. R. (1961) The ground substance; observations from electron microscopy. In: The Cell, Vol. 2. Eds. J. Brachet and A. E. Mirsky. Academic Press, New York.

REYNolds, E. S. (1963) The use of lead citrate at high $\mathrm{pH}$ as an electron-opaque stain in electron microscopy. 7. Cell Biol. 17, 208.

Schindler, H., Ben-David, E., Hurwitz, S. \& Kempenich, O. (1967) The relation of spermatozoa to the glandular tissue in the storage sites of the hen oviduct. Poult. Sci. 46, 1462.

TAKEDA, A. (1967) Behaviour of spermatozoa in the genital tract of the hen. IV. Persistence of spermatozoa and their transport in the hen's oviduct following artificial insemination. Fap. Poult. Sci. 4,62 .

Van Drimmelen, G. C. (1946) 'Spermnests' in the oviduct of the domestic hen. Fl S. Afr. vet. med. Ass. $17,42$.

VAN KREY, H. P. (1964) Storage and transport of spermatozoa within the oviduct of the domestic fowl. Ph.D. thesis, University of California.

Van Krey, H. P., Ogasawara, F. X. \& Pangborn J. (1967) Light and electron microscopic studies of possible sperm gland emptying mechanisms. Poult. Sci. 46, 69. 